\title{
Epididymal Toxicity Associated with Vincristine Treatment
}

\author{
T. SONAWANE* ${ }^{*}$ S. AZAZ1 ${ }^{1}$ K. HEMANT ${ }^{1}$ AND T. LIJI ${ }^{1}$
}

Amity Institute of Biotechnology, Amity University, Mumbai-410 206, ${ }^{1}$ School of Biotechnology and Bioinformatics, D. Y. Patil Deemed to be University, Mumbai-400 706, India

\section{Sonawane et al.: Epididymal Toxicity Associated with Vincristine}

\begin{abstract}
Vincristine, a major player in front line combination chemotherapy of cancer reduces testosterone levels contributing to reproductive toxicity. Much is known about testicular toxicity of vincristine as compared to its effect on epididymis; hence, the present study aimed to evaluate the epididymal toxicity associated with vincristine treatment, which also contributes to the overall reproductive toxicity associated with vincristine. Vincristine was intraperitoneally injected to adult male Wistar rats of proven fertility with a dose of $40 \mathrm{mg} / \mathrm{kg} / \mathrm{day}$ dissolved in $\mathbf{0 . 5} \mathrm{ml}$ of physiological saline for 30 days. The epididymal weight was found to be unaltered after treatment whereas sperm count was reduced significantly. Significant changes were noted in ion concentrations of cauda and caput of epididymis with changes in protein profile of the tissue, sperm and luminal protein from cauda and caput region, which plays a significant role in sperm maturation and sperm transport. Infertility associated with vincristine could be attributed to its effects on various epididymal proteins involved in sperm protection and various stages of sperm development such as cytoplasmic extrusion and membrane stabilization, which had contributed to the abnormal sperm count and impaired function.
\end{abstract}

Key words: Vincristine, epididymis, toxicity, ion concentration, sperm count

Vincristine (VCR) also known as leurocristine is a Vinca alkaloid derived from the Catharanthus roseus (Madagascar periwinkle) formerly Vinca rosea. VCR has been widely used as an anticancer drug because of its ability to inhibit cell division through prevention of polymerization of tubulin of the microtubules, which constitute the spindle fibre and the disassociation of the existing microtubules ${ }^{[1]}$. Although being a potent anticancer drug its use is limited due to a wide spectrum of side effects such as neurotoxicity, alopecia, colicky abdominal pain, myocardial infarction, optic atrophy and diplopia ${ }^{[2,3]}$. The male reproductive system consisted of actively dividing cells has also shown to be affected by VCR, thus compromising fertility ${ }^{[4]}$.

Epididymis being the site for sperm maturation is very important for the development of mature and motile sperm with fertilizing ability. The array of proteins and ions in the epididymis plays a vital role in maintaining the epididymal function ${ }^{[5]}$; even a slight modification would effects the metabolic pathways and ultimately result in compromised epididymal function. Several reports have suggested the impairment of epididymal functions and spermatogenesis on VCR administration $^{[6]}$ thereby affecting the levels of sperm maturation and transit proteins.

It has also been shown that apart from conventional male reproductive toxicity assessment by measuring the weight of reproductive organs such as testis, epididymis and prostate, analysis of sperm motility and viability, macroscopic and histological examination and changes in hormone levels ${ }^{[7,8]}$, the protein profile can also be used to evaluate the male reproductive toxicity ${ }^{[9-12]}$. The present study was aimed to evaluate the alterations in the sperm count, ion concentration and pattern of protein profile in cauda and caput after treatment with VCR thus leading to compromised epididymal functions.

\section{MATERIALS AND METHODS}

Male Wistar rats of proven fertility weighing 150-200 g

This is an open access article distributed under the terms of the Creative Commons Attribution-NonCommercial-ShareAlike 3.0 License, which allows others to remix, tweak, and build upon the work non-commercially, as long as the author is credited and the new creations are licensed under the identical terms

Accepted 20 April 2019

Revised 27 December 2018

Received 21 September 2018

Indian J Pharm Sci 2019;81(3):514-520 
(Bharat Serum and Vaccines Ltd, Mumbai) were maintained under standard laboratory conditions and were handled according to the institutional legislation regulated by the Committee for the Purpose of Control and Supervision of Experiments on Animals. They were allowed free access of food and water ad libitum (Amrut Feed Ltd).

\section{Drug and dose:}

VCR (Cytocristin, Cipla Ltd, Goa, India) was purchased from a local pharmacy and rats $(n=5)$ were injected intraperitoneally with $40 \mu \mathrm{g} / \mathrm{kg} / \mathrm{d}$ of VCR in $0.5 \mathrm{ml}$ of physiological saline while the control rats $(n=5)$ received $0.5 \mathrm{ml}$ of saline (ip) for $30 \mathrm{~d}$. At the end of the treatment period, animals were sacrificed under diethyl ether anaesthesia. The epididymis were quickly removed, blotted free of blood, weighed, snap frozen in liquid nitrogen and stored at $-80^{\circ}$ until used for further studies.

\section{Sperm count:}

The epididymal fluid was obtained by mincing of tissues in phosphate-buffered saline (PBS) followed by incubation of $30 \mathrm{~min}$ and centrifugation at $2500 \mathrm{rpm}$ for $2 \mathrm{~min}$. Sperm count was assayed by the method of Belsey et al. ${ }^{[13]}$. The total number of sperms was calculated using the following formula, total number of cell counted $\times 20$ (dilution factor) $/ 0.4 \mathrm{~mm}^{2}$ (total volume of the squares in which the cells were counted)

\section{Estimation of $\mathrm{Na}^{+}, \mathrm{K}^{+}$and $\mathrm{Mg}^{2+}$ :}

Luminal ions from caput and cauda of epididymis were extracted by the method described by Aranha et al. ${ }^{[14]}$. The extract was used for estimating $\mathrm{Na}^{+}, \mathrm{K}^{+}$and $\mathrm{Mg}^{2+}$ using an atomic absorption spectrophotometer (Chemito Instruments Pvt. Ltd, Worli, Mumbai, India).

\section{Protein extraction and quantification:}

The epididymal tissue samples were sequentially thawed, and dissected to separate individual segments, the cauda and caput. The epididymal segments were minced and incubated in $2 \mathrm{ml}$ of $0.1 \mathrm{M}$ PBS (pH 7.4) containing $0.1 \mathrm{M}$ phenylmethylsulfonyl fluoride (PMSF) for $30 \mathrm{~min}$ at $4^{\circ}$ to facilitate the release of sperms. The suspension was then pelleted by centrifugation at $2500 \mathrm{rpm}$ for $2 \mathrm{~min}$. The washing procedure was repeated at least 12 times until the tissue became sperm free.

The sperms were separated from the luminal proteins in sperm suspension by centrifuging at $4000 \mathrm{rpm}$ for
$10 \mathrm{~min}$. The supernatant containing luminal proteins were concentrated, dialyzed and stored at $-20^{\circ}$ in aliquots. Sperm protein extracts were prepared by lysing sperm pellet with a $1.5 \mathrm{ml}$ solubilisation buffer (Tris, $1 \%$ sodium dodecyl sulphate (SDS), $10 \%$ glycerol, $10 \mathrm{mM} \mathrm{PMSF}$ ) at $4^{\circ}$ at a final concentration of $0.75-4 \times 10^{5} \mathrm{sperm} / \mu \mathrm{l}$. The suspension was then vigorously vortexed for $3 \mathrm{~min}$.

Tissue extracts were prepared by homogenizing the tissues with $1.5 \mathrm{ml}$ solubilisation buffer (Tris, $1 \%$ SDS, $10 \%$ glycerol, $10 \mathrm{mM}$ PMSF) at $4^{\circ}$. The cellular debris was pellet at $11000 \mathrm{rpm}$ at $4^{\circ}$ for $15 \mathrm{~min}$. Samples were concentrated, dialyzed and stored at $-20^{\circ}$ before further treatments. The protein concentration of samples was estimated by Lowry's method ${ }^{[15]}$ using bovine serum albumin as the standard.

\section{Electrophoresis:}

About 30, 20 and $15 \mu \mathrm{g}$ of tissue, sperm and luminal protein samples were denatured in equal volume of gel loading buffer $(0.5 \mathrm{M}$ Tris-Cl $+10 \% \mathrm{SDS}+$ glycerol $+\beta$ mercaptoethanol $+0.025 \%$ bromophenol blue), in boiling water bath at $95^{\circ}$ for 5 min. Proteins were electrophoresed on a gradient SDS-polyacrylamide gel electrophoresis (PAGE) of 8-20 \% resolving gel and $5 \%$ stacking gel with a constant current of $35 \mathrm{~mA}$ until dye front entered the resolving gel, which was the increased to $55 \mathrm{~mA}$ thereafter till the dye front reached the end of the gel. Standard medium range molecular weight markers (Bangalore Genei, Mumbai) were also run along with tissue sample to determine the approximate molecular weight of sample proteins. Coomassie staining was carried out in order to observe the band pattern. Densitometry analysis of each sample and the standard markers were carried out on densitometer (Bio imaging, Syngene).

\section{Statistical analysis:}

Quantitative results are expressed as mean \pm SEM. The data were analysed by using independent student-t test and the differences in the control and treated groups were considered significant at $\mathrm{p}<0.05$.

\section{RESULTS AND DISCUSSION}

The epididymal weights of Wistar rat was found to be unaltered after treatment with VCR, at a dose of $40 \mu \mathrm{g} / \mathrm{kg}$ for a period of $30 \mathrm{~d}$, which is in contradiction with the previous reports, which has shown a decrease in the epididymis weight ${ }^{[16]}$. This variation is probably because of the difference in the drug dose administered 
to the rats. Sperm count is an important indicator of male fertility ${ }^{[17]}$ hence assessment of this parameter provides evidence on the effects of VCR on male fertility. A significant decrease $(\mathrm{p}<0.05)$ in the sperm count was observed in cauda $(27.30 \%)$ and caput $(36.04 \%)$ of treated rats compared with that of the control rats (fig. 1). The reduced sperm count observed in the current study could be due to the toxic effect of VCR on Leydig cells and testosterone levels, which was reported to cause sloughing of germinal epithelium and spermatogenesis ${ }^{[18]}$.

The concentration of sodium, potassium and magnesium in the cauda and caput regions of epididymis of control and VCR-treated rats are shown in Table 1. The metabolism, flagellar beating and acrosome reaction of spermatozoa are regulated by ion flux across the plasma membrane in mammals. Apical cells of epididymis play a major role in electrolyte transport for maturation events ${ }^{[19]}$. Sodium ions are the principal cations that induce motility of spermatozoa and potassium has additive effects depending on concentration, with higher concentration being inhibitory ${ }^{[14]}$. The decrease in sodium levels in caput and increase in magnesium

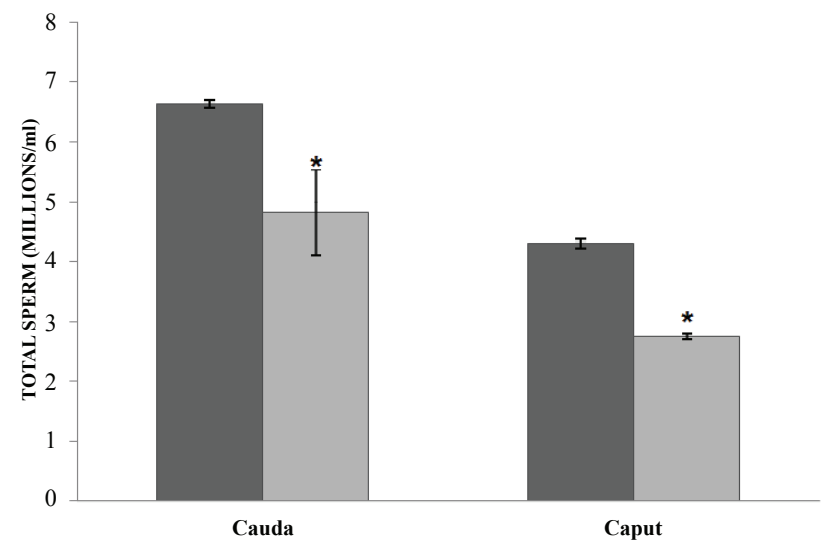

Fig. 1: Sperm count of cauda and caput segments of epididymis of control and treated rats

(घ) Control, ( $\square$ ) vincristine-treated; the values are expressed as mean \pm SEM $(p<0.05),{ }^{*} *$ indicates statistically significant change. The unit for total sperm count is millions $/ \mathrm{ml}$

TABLE 1: CONCENTRATION OF CATIONS IN CONTROL AND VCR-TREATED RAT EPIDIDYMAL CAUDA AND CAPUT

\begin{tabular}{lcccc}
\hline \multirow{2}{*}{ Tissue } & \multirow{2}{*}{ Type } & \multicolumn{3}{c}{ Ion concentration $(\mathrm{ppm})$} \\
\cline { 3 - 5 } & & Sodium & Potassium & Magnesium \\
\hline \multirow{2}{*}{ Cauda } & Control & $0.794 \pm 0.05$ & $0.82 \pm 0.005$ & $0.104 \pm 0.02$ \\
& Treated & $0.753 \pm 0.05$ & $0.78 \pm 0.04$ & $0.144^{*} \pm 0.01$ \\
\multirow{2}{*}{ Caput } & Control & $1.221 \pm 0.08$ & $0.72 \pm 0.03$ & $0.120 \pm 0.02$ \\
& Treated & $0.808^{*} \pm 0.04$ & $0.68 \pm 0.04$ & $0.136 \pm 0.02$ \\
\hline
\end{tabular}

The values are expressed as mean \pm SEM $(p<0.05)$, “*' indicates statistically significant change

May-June 2019

Indian Journal of Pharmaceutical Sciences concentration of cauda seen in the present study could lead to an inhibitory effect on sperm motility of both caput and cauda region on VCR treatment, as optimal concentrations of these cations are required for sperm motility, which is specific for each species.

The total protein concentrations of tissue, sperm and luminal tissue from 3 treated and 3 control rat cauda and caput were determined using Folin Lowry method. No significant changes were observed in treated samples when compared with control (Table 2). Though there were no significant changes observed in total protein concentration, alteration in protein profile of these samples were noted when tissue, sperm and luminal extracts of epididymis was separated on gradient (8-20\%) SDS PAGE and band patterns were analysed using densitometry (Bio Imaging System, Syngene).

In all the samples, separation of the proteins revealed the presence of approximately 10-16 polypeptides ranging in size $12-280 \mathrm{kDa}$ with major bands lying between $14-120 \mathrm{kDa}$ (fig. 2). In cauda tissue protein, the densitometry graph (fig. 2A) showed that the polypeptide of molecular weight $66 \mathrm{kDa}$ of treated samples did not show any change in the expression levels with respect to control samples. On the other hand peptides from the treated sample with molecular weight of $160,95,80,41,38,27,24,19,16$ and $13 \mathrm{kDa}$ showed increase whereas the one with the molecular weight of $31 \mathrm{kDa}$ showed slight decrease in expression levels when compared to control samples. In caput tissue, the densitometry graph (fig. 2B) revealed that no polypeptides of treated samples showed any change in the expression levels with respect to control samples except that hose with molecular weight of 28, 20 and $14 \mathrm{kDa}$ showed slight increase in the treated samples as compared to control.

In cauda sperm proteins, the densitometry graph (fig. 2C) showed that the polypeptide of molecular weight $17 \mathrm{kDa}$ of treated samples did not show any change in the expression levels with respect to control samples. On the other hand, rest of all peptides from the treated sample showed increase when compared with control samples. In cauda sperm proteins, the densitometry graph (fig. 2D) showed that the polypeptide of molecular weight $17 \mathrm{kDa}$ of treated samples did not show any change in the expression levels with respect to control samples. On the other hand, rest all peptides from the treated sample showed increase in expression levels when compared with control samples. 
www.ijpsonline.com

A.
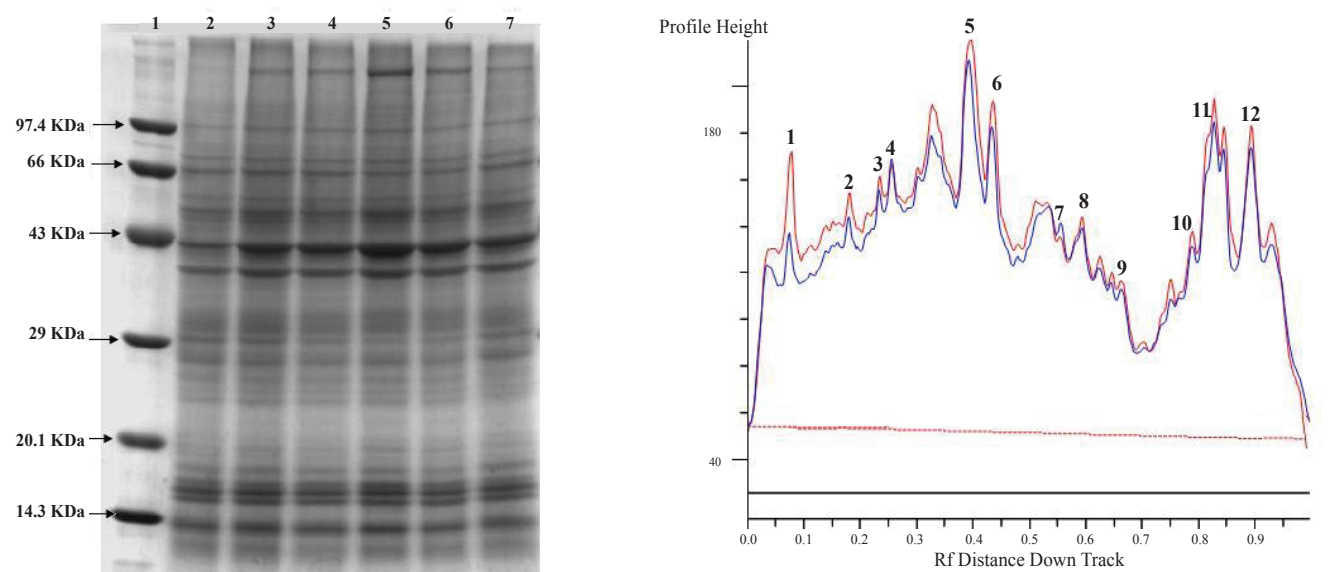

A.
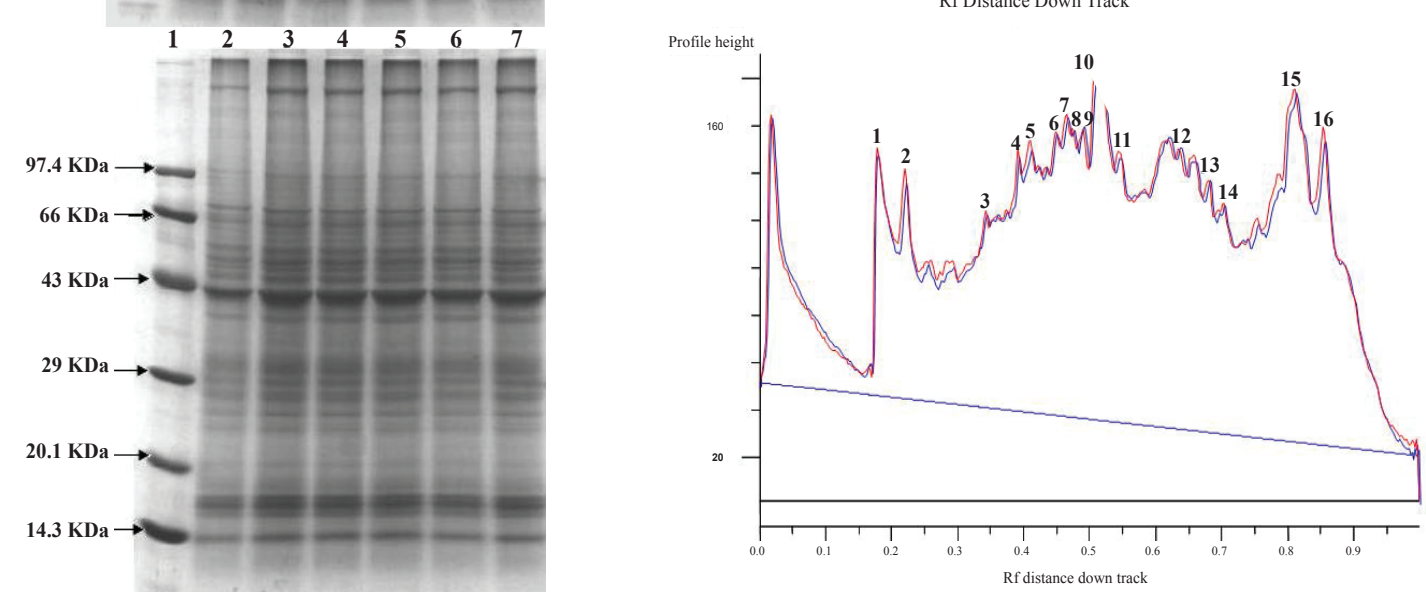

B.

C.
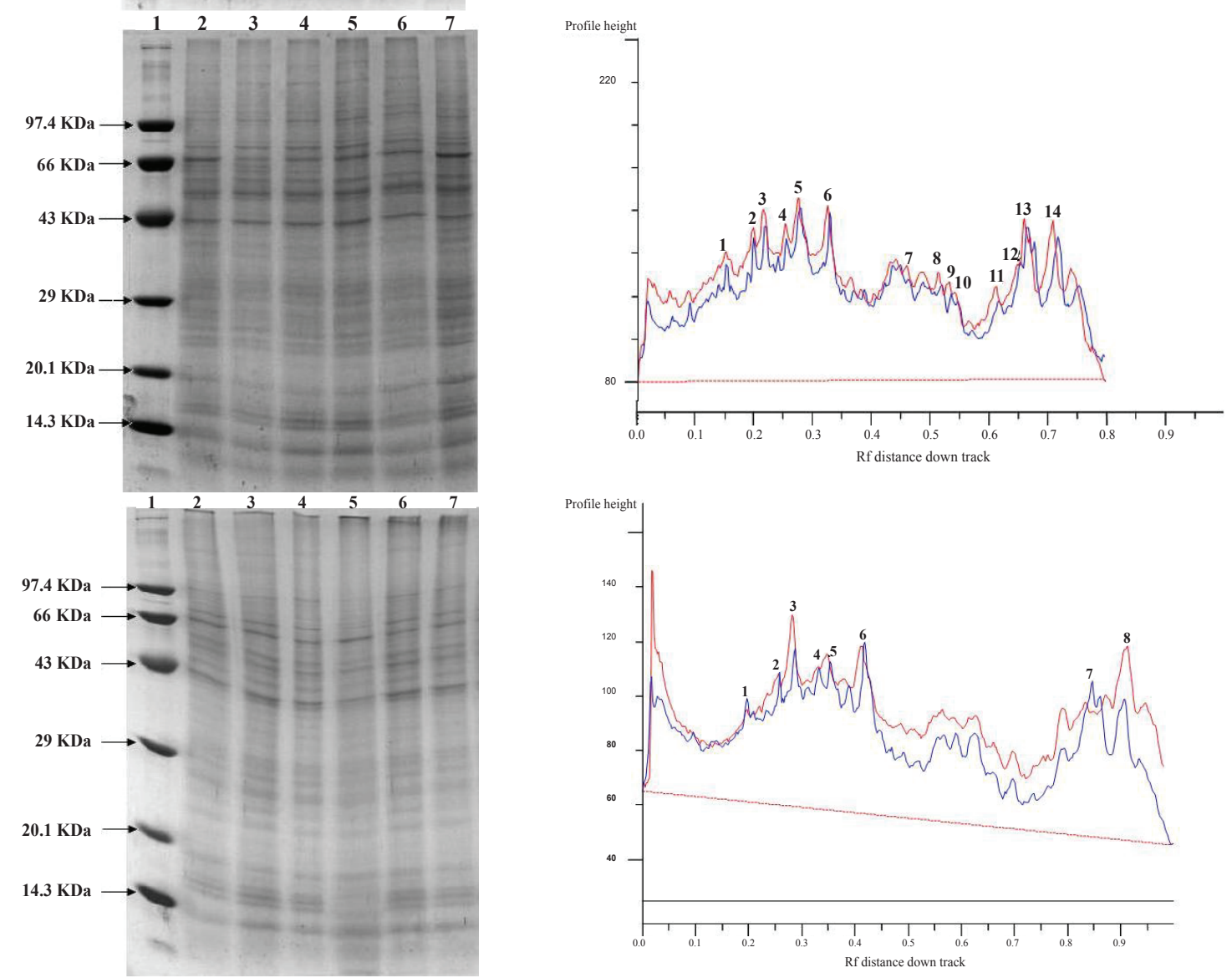
www.ijpsonline.com

E.
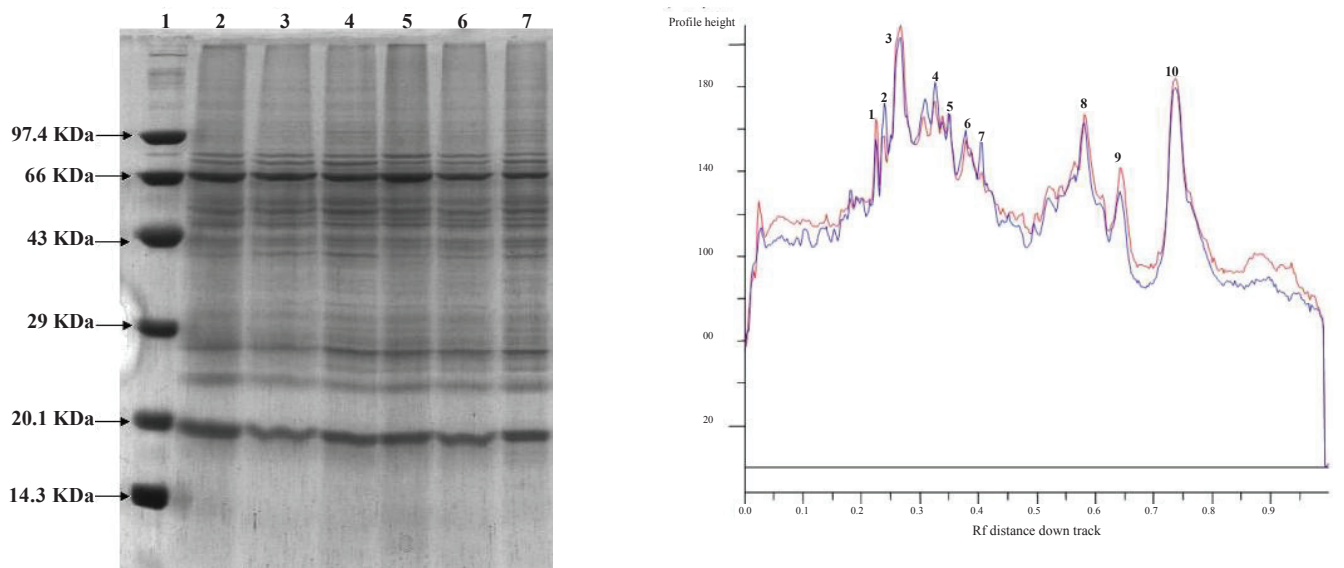

F.
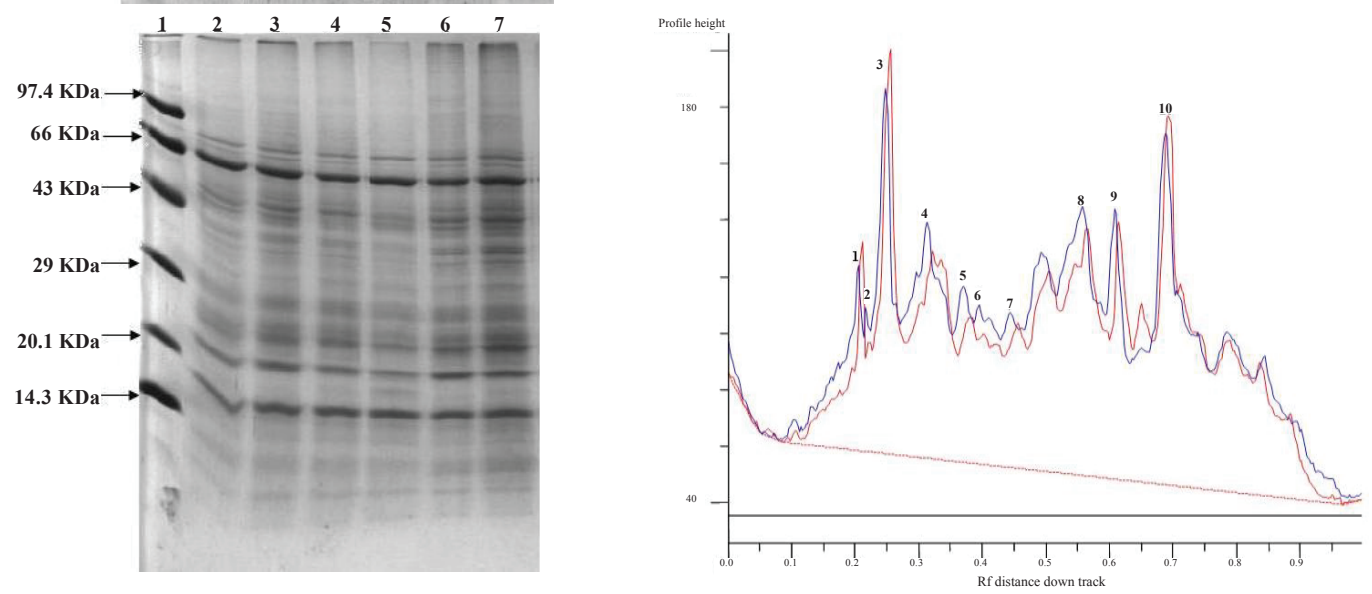

Fig. 2: Gradient-SDS PAGE (8-20 \%) gel electrophoresis showing protein profiling and densitometry graph

A: control and vincristine-treated rat epididymal cauda tissue protein; B: control and vincristine-treated rat epididymal caput tissue protein; C: control and vincristine-treated rat epididymal cauda sperm protein; D: control and vincristine-treated rat epididymal caput sperm protein; E: control and vincristine-treated rat epididymal cauda luminal protein; F: control and vincristine-treated rat epididymal caput luminal protein. Lane 1: corresponds to medium range marker. Lanes 2, 3, 4 display tissue protein profiles of epididymal cauda of control rats, lanes 5, 6, 7 display tissue protein profiles epididymal cauda of treated rats. $30 \mu \mathrm{g}$ of proteins of control and treated were loaded in each well

TABLE 2: PROTEIN LEVELS OF CAUDA AND CAPUT OF CONTROL AND TREATED RATS

\begin{tabular}{lcccc}
\hline \multirow{2}{*}{ Tissue } & & \multicolumn{3}{c}{$\begin{array}{c}\text { Average protein concentration } \\
\text { (mg/g of tissue) }\end{array}$} \\
\cline { 3 - 5 } & Type & $\begin{array}{c}\text { Tissue } \\
\text { protein }\end{array}$ & $\begin{array}{c}\text { Sperm } \\
\text { protein }\end{array}$ & $12.16 \pm 2.78$ \\
\hline \multirow{2}{*}{ Cauda } & Control & $10.82 \pm 0.93$ & $3.55 \pm 0.04$ & $8.64 \pm 0.61$ \\
& Treated & $12.51 \pm 0.72$ & $4.35 \pm 0.05$ & $11.93 \pm 1.85$ \\
& Control & $18.17 \pm 0.84$ & $6.96 \pm 0.11$ & $12.64 \pm 0.87$ \\
& Treated & $15.55 \pm 1.87$ & $5.99 \pm 0.08$ & $12.16 \pm 2.78$ \\
\hline
\end{tabular}

The values are expressed as mean \pm SEM $(p<0.05)$

In cauda luminal proteins, the densitometry graph (fig. 2E) showed that the polypeptides of molecular weights 50 and $45 \mathrm{kDa}$ of treated samples did not show any change in the expression levels with respect to control samples. On the other hand, peptides with molecular weights 93, 70, 27, 24 and $19 \mathrm{kDa}$ from the treated sample showed increase whereas the polypeptides with molecular weights 81,55 and
$43 \mathrm{kDa}$ showed slight decrease respectively in expression levels when compared with control samples. In caput luminal proteins, the densitometry graph (fig. 2F) showed increase expression of peptides with molecular weights 65,53 and $14 \mathrm{kDa}$ whereas the polypeptides with molecular weights $61.5,43,41,35$, 29, 21 and $18 \mathrm{kDa}$ showed slight decrease respectively in expression levels when compared with control samples.

The $24 \mathrm{kDa}$ protein level in tissue, sperm and lumen of cauda was increased in response to VCR treatment. On the basis of molecular weight comparison it likely to be glutathione peroxidase type 5 ( $24 \mathrm{kDa}$; GPX5), present in principal cells, sperm and lumen of caput and cauda, which plays a vital role in protecting the membranes of spermatozoa from the damaging effect of lipid peroxidation (by inactivating hydrogen peroxides and organic hydroperoxides) and/or preventing premature acrosome reaction ${ }^{[20]}$. The increase in the antioxidant 
enzyme, GPX5 protein suggested that the epididymis is probably exposed to oxidative stress on VCR treatment.

Two proteins of molecular weight $19 \mathrm{kDa}$ and $14 \mathrm{kDa}$ from tissue, sperm and lumen of caput, which were found to be depleted on VCR treatment, could most likely be glycosylated isoform of cystatin-related epididymal spermatogenic (CRES) and non-glycosylated isoform of CRES. CRES defines a new subgroup in the family 2 cystatins of cysteine protease inhibitors by virtue of its reproductive specific expression ${ }^{[21]}$. It inhibits the serine protease pro-hormone convertase 2 (PC2), a subtilisin/ Kex2p-like endoprotease involved in prohormone processing required for spermatogenesis ${ }^{[16]}$. CRES increase might halt spermatogenesis due to increased inhibition of $\mathrm{PC}^{[22]}$. This could be one of the probable reasons for depletion of sperm in epididymis on treatment with VCR.

In case of treated caput and cauda tissue, the level of a protein of molecular weight $27.5 \mathrm{kDa}$ was increased, which is most likely to be galectin-3 $(27.5 \mathrm{kDa})$, an IgE binding protein endogenous soluble lectin within the family called galectins that bind beta-galactosides. It is found to be localized primarily in the nucleus of the duct epithelial cells and has shown to be a necessary factor in the splicing of nuclear pre-mRNA ${ }^{[23]}$. A $30.41 \mathrm{kDa}$ caudal tissue protein that showed decrease on VCR treatment was thought to be HOXBES2 protein $(30 \mathrm{kDa})$. Its decrease could lead to abnormalities in sperm physiology. In previous studies, a novel $30 \mathrm{kDa}$ sperm homeoprotein, termed as HOXBES2 (HOXB2 homeodomain containing epididymis-specific sperm protein) has potential GPI modification site, which is required for proper acquisition of luminal proteins by spermatozoa during maturation ${ }^{[24]}$. The decrease in the protein could lead to hamper in acquisition of protein by spermatozoa leading to impaired sperm maturation.

The luminal proteins from caput region, showed a decrease in $61.5 \mathrm{kDa}$ protein which is probably gamma glutamyl-transpeptidase (GGT), that plays a vital role in sperm thiol oxidation required for sperm maturation and motility ${ }^{[23]}$. This reduction in GGT could be because of depletion seen in $40 \mathrm{kDa}$ luminal protein from both caput and cauda region, which is most likely to be basic-fibroblast growth factor found to be involved in regulation of GGT activity and GGT protein level in epididymis via MAP kinase pathway ${ }^{[25]}$. A $26.8 \mathrm{kDa}$ caudal luminal protein was found to be increased on treatment with VCR. This protein might be triosephosphate isomerase-1, which plays a role in sperm activity by acting on its metabolism ${ }^{[26]}$.

The analysis of sperm proteins revealed an increase in caudal sperm proteins of molecular weight 60 and $27 \mathrm{kDa}$ in treated rats as compared to control, which are likely to be fertilin $\beta$ and phosphotyrosine phosphatase (PTP), respectively. Fertilin $\beta$ is a member of a growing family of sequence-related proteins called the metalloproteinase-like, disintegrin-like, cysteine-rich (MDC) family, and acts in regulation of spermatogenesis, sperm-oocyte binding and sperm-oolemma membrane fusion ${ }^{[27]}$ whereas PTP negatively controls the level of any particular protein phosphotyrosine that regulates sperm capacitation and motility ${ }^{[28,29]}$. However, a $84.8 \mathrm{kDa}$ caudal sperm protein showed a significant decrease on treatment, which could probably be Gelsolin $(85.4 \mathrm{kDa})$ that plays a key role in regulating vacuolar V-ATPase recycling, which in turn helps in maintaining optimum $\mathrm{pH}$ required for sperm maturation and storage ${ }^{[30]}$. A caput sperm protein of $37 \mathrm{kDa}$, showed a slight decrease on treatment with VCR, which is probably lactate dehydrogenase. It shows primary metabolism activity and probably helps in the maturation of sperms. Apart from these, changes were also observed in sperm proteins of molecular weight 90 and $74 \mathrm{kDa}$ from caput and cauda, respectively, which could be $\beta$-D-galactosidase, an exo-glycosidase in intracellular digestion of specific terminal glycosyl residues from glycoproteins and glycolipids ${ }^{[31]}$.

Epididymis being the site of sperm development and maturation, any change in the ion concentration and the proteins that might play a role in various processes of sperm maturation and transit through the epididymal duct, would eventually lead to impaired sperm count as observed in the present study and further possibly to compromised sperm function. The rate of sperm movement and the protein acquisition by the sperms during its transit through epididymal lumen governs the sperm maturation event. Thus, alteration in proteins involved in sperm transport could lead to incomplete development of sperms. Additionally, variations in concentrations of sodium, potassium and magnesium ions could also be detrimental to sperm motility. These alterations in proteins involved in sperm protection and various stages of sperm development such as cytoplasmic extrusion and membrane stabilization might further contribute to the abnormal sperm count and impaired function, thus leading to infertility. 


\section{Conflicts of interest:}

The authors declare that there is no conflict of interest.

\section{Financial support and sponsorship:}

Nil.

\section{REFERENCES}

1. Stanton RA, Gernert KM, Nettles JH, Aneja R. Drugs That Target Dynamic Microtubules: A New Molecular Perspective. Med Res Rev 2011;31(3):443-81.

2. Kamil N, Kamil S, Ahmed SP, Ashraf R, Khurram M, Ali MO. Toxic effects of multiple anticancer drugs on skin. Pak J Pharm Sci 2010;23:7-14.

3. Gomber S, Dewan P, Chhonker D. Vincristine Induced Neurotoxicity in Cancer Patients. Ind J Ped 2010;77:97-100.

4. O'Donnell L, Stanton P, de Kretser DM. Endocrinology of the Male Reproductive System and Spermatogenesis. [Updated 2017 Jan 11]. In: Feingold KR, Anawalt B, Boyce A, Chrousos G, Dungan K, Grossman A, et al., editors. Endotext. [Internet]. South Dartmouth (MA): MDText.com, Inc.; 2000.

5. Turner TT, Bomgardner D, Jacobs JP, Nguyen QA. Association of segmentation of the epididymal interstitium with segmented tubule function in rats and mice. Reproduction 2003;125:87178.

6. Meistrich ML. Effects of chemotherapy and radiotherapy on spermatogenesis in humans. Fertil Steril 2013;100(5):1180-6.

7. Khaki A. Assessment on the adverse effects of Aminoglycosides and Flouroquinolone on sperm parameters and male reproductive tissue: A systematic review. Iran J Reprod Med 2015;13:125-34.

8. Pompe SV, Strobach D, Stief C, Becker A, Trottmann M. Drug use among men with unfulfilled wish to father children: a retrospective analysis and discussion of specific drug classes. Pharmacoepidemiol Drug Saf 2016;25:668-77.

9. Ostermeier GC, Dix DJ, Miller D, Khatri P, Krawetz SA. Spermatozoal RNA profiles of normal fertile men. Lancet 2002;360:772-7.

10. Krawetz SA. Paternal contribution: New insights and future challenges. Nat Rev Genet 2005;6:663-42.

11. Wang $\mathrm{H}$, Zhou Z, Xu M, Li J, Xiao J, Xu ZY, et al. A spermatogenesis-related gene expression profile in human spermatozoa and its potential clinical applications. J Mol Med 2004;82:317-24.

12. Sousa M, Ferreira C, Rabaca A, Sa R. Assessing Male Reproductive Toxicity during Drug Development. Andrology 2017;6:185

13. World Health Organization. WHO laboratory manual for the examination and processing of human semen. 5th ed. Singapore: WHO Press Conference; 1980. Available from: http://www.who.int/iris/handle/10665/44261.

14. Aranha I, Bhagya M and Yajurvedi HN. Concentration of cations in different parts of male reproductive system and their influence on in vitro sperm motility in lizards, Mabuya carinata Schneider. Ind J Exp Biol 2008;46:720-24.

15. Lowry $\mathrm{OH}$, Rosebrough NJ, Farr AL, Randall RJ. Protein measurement with the Folin phenol reagent. J Biol Chem 1951;193:265-75.
16. Oskooii AE, Gholizad LM, Zare S, Nejati V. A Comparison of Effects of ABVD and ChlVPP Chemotherapeutic Protocols for Hodgkin's disease on Rats Epididiymal and Testicular Tissues. Pak J Biol Sci 2010;13:884-90.

17. Kumar N, Singh AK. Trends of male factor infertility, an important cause of infertility: A review of literature. J Hum Reprod Sci 2015;8(4):191-6.

18. Nikpour F, Tayefi H, Mohammadnejad D, Akbarzadeh A. Adverse Effects of Vincristine Chemotherapy on Cell Changes in Seminiferous Tubules and Cetrorelix GnRH Antagonist Inhibitory Effects in Mice. Asian Pac J Cancer Prev 2018;19(3):683-7.

19. Averal HI, Stanley A, Murugaian P, Palanisamy M, Akbarsha MA. Specific effect of vincristine on epididymis. Ind J Exp Biol 1996;34:53-6.

20. Williams K, Frayne J, Hall L. Expression of extracellular glutathione peroxidase type 5 (GPX5) in the rat male reproductive tract. Mol Hum Reprod 1998;4:841-8.

21. Cornwall GA, Cameron A, Lindberg I, Hardy DM, Cormier N, Hsia N. The Cystatin-Related Epididymal Spermatogenic Protein Inhibits the Serine Protease Prohormone Convertase 2. Endocrinology 2003;3:901-8.

22. Cornwall GA, Hann SR. Specialized gene expression in the epididymis. J Androl 1995; 16:379-83.

23. Yuan H, Liu A, Zhang L, Zhou H, Wang Y, Zhang H, et al. Proteomic profiling of regionalized proteins in rat epididymis indicated consistency between specialized distribution and protein functions. J Prot Res 2006;5:299-307.

24. Prabagaran E, Hegde UC, Moodbidri SB, Bandivdekar AH, Raghavan VP. Postnatal Expression and Androgen Regulation of HOXBES2 Homeoprotein in Rat Epididymis. J Androl 2007;28:755-71.

25. Lan ZJ, Labus JC, Hinton BT. Regulation of GammaGlutamyl Transpeptidase Catalytic Activity and Protein Level in the Initial Segment of the Rat Epididymis by Testicular Factors: Role of Basic Fibroblast Growth Factor. Biol Reprod 1998;58:197-206.

26. Bone W, Jones NG, Kamp G, Yeung CH, Cooper TG. Effect of ornidazole on fertility of male rats: inhibition of a glycolysis-related motility pattern and zona binding required for fertilization in vitro. J Reprod Fertil 2000;118:127.

27. McLaughlin EA, Frayne J, Barker HL, Jury JA, Jones $\mathrm{R}$, Ford WC, et al. Cloning and sequence analysis of rat fertilin $\alpha$ and $\beta$ : developmental expression, processing and immunolocalization. Mol Hum Reprod 1997;3:801-9.

28. Hunter T. Protein kinases and phosphatases: the yin and yang of protein phosphorylation and signaling. Cell 1995;80:22536.

29. Brautigan DL. Great expectations: protein tyrosine phosphatases in cell regulation. Biochim Biophys Acta 1992;1114:63-77.

30. Beaulieu V, Da Silva N, Pastor-Soler N, Brown CR, Smith PJ, Brown D, et al. Modulation of the Actin Cytoskeleton via Gelsolin Regulates Vacuolar H-ATPase Recycling. J Biol Chem 2005;280:8452-63.

31. Chayko CA, Orgebin-Crist MC. Targeted disruption of the cation-dependent or cation-independent mannose 6-phosphate receptor does not decrease the content of acid glycosidases in the acrosome. J Androl 2000;21:944-53. 